\title{
EL PROCESO MONITORIO EN COLOMBIA: RAZONES PARA UNA OBJECIÓN*
}

\author{
Semillero de Derecho Procesal \\ Universidad del Rosario. Facultad de Jurisprudencia \\ Sharah Liliana Aguirre Lemusi, David Cujar Bermúdezi, \\ Andrea Carolina Torres Sarmientoiii, Gabriela Zapata Castaño ${ }^{i v}$ \\ Director del Semillero: Gabriel Hernández Villarealv
}

\section{Resumen}

Justificar el modelo documental del proceso monitorio y demostrar que debió ser adoptado por el Código General del Proceso colombiano es el objetivo del presente artículo, teniendo en cuenta que este es directriz en Latinoamérica por ser garantía de seguridad jurídica. Por tal motivo, la tesis pretende señalar una objeción al modelo "puro" acogido en Colombia por sus inconsistencias, pues: 1) Fortalece los criterios subjetivos de valoración por parte del juez, porque se acoge como plena

Recibido: septiembre 11 de 2015 - Aprobado: julio 11 de 2016.

* Artículo inédito.

Para citar el artículo: TORRES SARMIENTO, Andrea Carolina; CUJAR BERMÚDEZ, David; AGUIRRE LEMUS, Sharah Liliana; et al. Revista del Instituto Colombiano de Derecho Procesal. No. 44, julio- diciembre. 2016. Bogotá: Instituto Colombiano de Derecho Procesal. pp. 67-102.

Este artículo fue presentado como trabajo de investigación en el XVI Concurso para Estudiantes de Derecho - Nivel Pregrado, 2016 en el marco del XXXVI Congreso Colombiano de Derecho Procesal, quedando dentro del cuadro de honor y entre los mejores trabajos escritos.

i Egresada de la Facultad de Jurisprudencia de la Universidad del Rosario, miembro del semillero de Derecho Procesal, Monitora de Derecho Comercial y Pasante en la Firma Brigard \& Urrutia.

ii Estudiante de IX semestre de Jurisprudencia de la Universidad del Rosario, miembro del semillero de Derecho Procesal, Monitor de Derecho Constitucional Comparado y miembro del Grupo de Acciones públicas de la misma universidad. 
El proceso monitorio en Colombia: razones para una objeción

prueba a simples afirmaciones de una de las partes inmersas previamente en una supuesta relación jurídico-sustancial. 2) Genera la desigualdad de las partes intervinientes en el proceso, porque la carga probatoria demandante y demandado será desproporcionada al exigirle a este último aportar una prueba para poder formular con éxito su oposición. 3) Desconoce de garantías constitucionales al permitir a un sujeto iniciar un juicio monitorio a partir de una obligación desprovista de un principio de prueba escrito, lo cual posibilita además que cualquier agente formule la demanda, incluso aquel que ostente un gran poder económico y una posición dominante en el mercado. Al mismo tiempo, este texto desarrolla el argumento que apoya la necesidad de la existencia de un principio de prueba documental, expone las nocivas consecuencias que representa la existencia de las "medidas cautelares" en el proceso monitorio puro en el contexto colombiano actual y revela que es el modelo documental es que mejor se ajusta al ordenamiento colombiano, teniendo en cuenta que como las reglas de la experiencia indican, se convertirá en la mejor alternativa para resolver conflictos entre las partes que cumplan los requisitos para acceder a la justicia por esa vía.

Palabras clave: proceso monitorio documental, Derecho comparado, trasplantes jurídicos, legislación colombiana, debido proceso, medidas cautelares.

\section{Abstract}

To justify the "Monitory documental payment procedure" (proceso monitorio documental) and to demonstrate that it should be adopted

iii Estudiante en proceso de grado, X semestre de Jurisprudencia de la Universidad del Rosario, miembro del semillero de Derecho Procesal, monitora de Derecho Procesal Civil y joven investigadora de la línea de Derecho Privado de dicha institución.

iv Administradora de Negocios Internacionales de la Universidad del Rosario (2014) y estudiante de IX semestre de jurisprudencia de la misma institución, miembro del semillero de Derecho Procesal.

v Abogado egresado de la Facultad de Jurisprudencia de la Universidad del Rosario, especialista en derecho procesal civil de la misma institución. Conjuez de la Sala Civil del Tribunal Superior del Distrito Judicial de Bogotá. Director de las Especializaciones en Derecho Procesal y en Derecho Probatorio de la Universidad Colegio Mayor de Nuestra Señora del Rosario y director de su Área de Derecho Procesal. Magíster en Derecho Procesal por la Universidad Externado de Colombia y Maestrando en Derecho Procesal de la Universidad Nacional de Rosario, Argentina y candidato a Doctor en Derecho por la misma Universidad. Presidente del Capítulo Colombia del Instituto Panamericano de Derecho Procesal y miembro de los Institutos Colombiano e Iberoamericano de Derecho Procesal. Miembro de la subcomisión redactora de la reforma al Código de Procedimiento Civil, la cual culminó con la expedición de la ley 1395 de 2010. Litigante y asesor. 
Semillero de Derecho Procesal. Universidad del Rosario. Facultad de Jurisprudencia

in the Colombian General Procedure Code is the main objective of this article, because this kind of procedure in particular, constitutes a directive in Latinoamerica for be a guarantee of juridical security. For that reason, our thesis pretends to expose an objection to the "Monitory pure payment procedure" (proceso monitorio puro) introduced in Colombian Law because of its inconsistencies: 1) It fortifies the subjective criteria of the judge, because it admits like full proof affirmations of just one of the parties involved in a previous legal-substantial relation. 2) It produces an unequal situation between the parties in the procedure considering that the burden of proof becomes non-proportional when is the defendant who should supply a proof to have success in the opposition. 3) It disclaims constitutional guarantees allowing a person to initiate the Monitory procedure from an obligation without a certified proof in writing, accepting that anybody could demand, including who have a dominant position in the market or an economical power. At the same time, this text contains the argument that supports the necessity of the existence of a principle of documentary proof, and we expose the harmful consequences that represent the existence of the "precautionary measures" in the pure payment procedure in the actual Colombian context. The investigation also reveals that the documental payment procedure is the model that fits better to Colombian legal necessities, and like the 'rules of experience' state it will become the best alternative to solve conflicts between the parts that accomplish the requirements to access to justice in that way.

Key words: Documental payment procedure, sociology, anthropology, legal transplants, Colombian legislation, precautionary measures.

\section{Introducción}

En el contexto global, el proceso monitorio ha tenido tan amplia acogida que hoy por hoy se constituye como apología a la eficiencia y al ágil cobro de créditos de demandantes que no cuentan con un título ejecutivo para asegurar su acreencia por esa vía, pero que pretenden pre-constituirlo de forma expedita para materializar su derecho. Por ese motivo, ha sido adoptado gradualmente en los diferentes códigos de Procedimiento Civil de la mayoría de países latinoamericanos y es considerado por importantes académicos en el campo del Derecho como deidad jurídica ${ }^{1}$ por su contribución a la celeridad de las actuaciones judiciales, su aporte en la persecución de una "finalidad social" al facilitar el acceso a la justicia y la materialización del

CALVINHO, Gustavo. Debido proceso y procedimiento monitorio. VV.AA, Director Alvarado Velloso - Zorzoli, Ediar, 2006. p. 2. 
El proceso monitorio en Colombia: razones para una objeción

derecho a la tutela efectiva del crédito de quienes son acreedores de obligaciones informales ${ }^{2}$.

En consecuencia, la tesis principal del presente escrito pretende exponer las razones por las cuales Colombia debió optar, en lugar del proceso monitorio "puro", por el documental, teniendo en cuenta que este último modelo es directriz en Latinoamérica por ser garantía de seguridad jurídica. En ese sentido, se expondrá el desarrollo del proceso monitorio en los países latinoamericanos como auténtica tendencia del Derecho Procesal ${ }^{3}$ para resaltar que, contrario a lo que sucedió en nuestro país, existe un factor común en las diferentes legislaciones internas que ya lo han adoptado, este es la necesidad de aportar un principio de prueba documental.

Consecuentemente con lo dicho, se hará énfasis en el trasplante jurídico ${ }^{4}$ de la figura del proceso monitorio en el caso particular de Colombia como Estado receptor, en consideración a que la mencionada institución se introdujo por primera vez en el contexto nacional. De igual forma, se presentarán los motivos por los que el modelo puro no atiende a las tradiciones socio-jurídicas, las necesidades y las particularidades propias del ordenamiento interno colombiano. Además, se analizarán las disposiciones del Código General del Proceso desde la sociología jurídica para resaltar la trascendencia que el proceso monitorio tendría de haber sido adoptado como documental.

Como argumento adicional se desarrollará un estudio respecto de las principales particularidades del proceso monitorio puro en el ámbito jurídico colombiano. Para el efecto, se confrontarán temas de alta relevancia como las medidas cautelares y el alcance de la providencia proferida en el marco de dicho proceso. Lo anterior para explicar en concreto que el medio más idóneo habría sido concebir el régimen de tarifa legal, en lo que a valoración de los medios probatorios respecta, como excepción a la regla general de la sana crítica y evitar así la inseguridad que se generará del hecho de acoger como plena prueba simples afirmaciones o negaciones ${ }^{5}$ de una de las partes inmersas previamente en una supuesta relación jurídico-sustancial.

REPÚBLICA DE COLOMBIA. Corte Constitucional. Sentencia C-726 de 2014.

3 QUINTERO, Magda; BONETT, Samir. "El proceso monitorio: tendencia del Derecho procesal Iberoamericano". Ponencia en el Concurso para Abogados en el marco de las XXIV Jornadas Iberoamericanas de Derecho Procesal, organizadas por el Instituto Iberoamericano de Derecho Procesal y el Instituto Colombo Panameño de Derecho Procesal, en Ciudad de Panamá, el 26, 27 y 28 de marzo de 2014.

4 LÓPEZ MEDINA, DiegoEduardo. Teoría impura del Derecho, la transformación de la cultura jurídica latinoamericana. Colombia: Editorial Legis, 2008. pp. 8 - 11.

5 HERNÁNDEZ, Gabriel. La reforma al proceso ejecutivo: estudio del impacto que sobre este tiene el análisis económico del Derecho. Editorial Universidad del Rosario, Facultad de jurisprudencia, 2014. p 40. 
En el desarrollo del tema plasmado en el texto, se hará énfasis en la importancia del documento como principio de prueba y correlativamente se advertirá que el modelo puro generará problemáticas como: el fortalecimiento de los criterios subjetivos de valoración por parte del juez, porque se rompe con el presupuesto de imparcialidad; se propiciará la desigualdad de las partes intervinientes en el proceso, porque la carga probatoria del demandante y del demandado será desproporcionada; se desconocerán garantías superiores como las que se desprenden del debido proceso y se dará un alcance extremadamente amplio a la declaración unilateral que haga el presunto acreedor de una obligación desprovista de un principio de prueba por escrito. Esta, por lo demás, puede ser formulada ante los estrados judiciales por cualquier agente, incluido aquel que ostente un gran poder económico y una posición dominante en el mercado, toda vez que en el proceso monitorio no se tiene prevista una cualificación del demandante en este sentido.

Finalmente, el presente escrito se enfoca en llegar a conclusiones y propuestas de aplicabilidad de la figura en Colombia, por la relevancia que su adopción implica y porque como las reglas de la experiencia y las circunstancias fácticas de la práctica latinoamericana lo demuestran, este proceso se constituirá como la figura "estrella" con la entrada en vigencia del Código General del Proceso.

\section{Defensa del proceso monitorio documental}

El propósito del proceso monitorio es proporcionar un instrumento de tutela que otorgue mayor agilidad que un proceso declarativo ordinario común en ciertos ámbitos de la actividad económica ${ }^{6}$. Sus cualidades y ventajas respecto a otros procesos han impulsado su implementación en distintos países del mundo, lo cual ha permitido la pronta solución de controversias, debido a la simplicidad de su trámite. Es por esto que legisladores de diversas latitudes se han esforzado en adaptar el proceso monitorio al contexto del ordenamiento correspondiente con el fin de lograr su correcto establecimiento.

Es entonces relevante proceder con la revisión de ciertos aspectos de fondo del proceso monitorio, uno de ellos es el efecto e impacto jurídico que trae para un ordenamiento su aplicación en la modalidad de puro o documental. Es así, porque el desarrollo de estos procesos puede no ser satisfactorio si se implementa de forma equivoca alguna de las modalidades del proceso monitorio, discordancia que a su vez trae la posibilidad de que se presenten conflictos en la aplicación de las normas y en el desarrollo de procedimientos y trámites ante las diferentes autoridades judiciales. Por esta razón, es necesario analizar si los objetivos del legislador colombiano se podrían materializar en la realidad nacional.

6 MONTERO, Juan. El proceso monitorio (tema 38). Edición séptima. Tomo II. España: Tirant Lo Blanch, 2012. p. 5. 
El proceso monitorio en Colombia: razones para una objeción

\section{Teorías trasnacionales y trasplantes jurídicos y su justificación en el proceso monitorio}

En general, el proceso se constituye en uno de los aspectos más importantes para el mundo del Derecho por su intento de dirimir las controversias que surgen de la cotidianidad y que, a partir de su análisis, pueden conducir a un manejo adecuado de las instituciones jurídicas y brindar armonía entre el Estado y la sociedad. Por ese motivo, deben examinarse las condiciones reales en las cuales se da el proceso ${ }^{7}$, pues, como lo señala Gregorio Robles, existe una "inundación procesal", la cual consiste en determinar "la multiplicación de procesos judiciales, motivada por la mayor juridificación de la vida, la mayor sensibilidad ante los problemas jurídicos y el mayor conocimiento de los mecanismos que el derecho pone a la disposición de los ciudadanos para resolverlos"8.

Lo anterior se traduce en la invitación del Estado a las personas para que participen y retomen la confiabilidad en la jurisdicción que de tiempo atrás se ha venido desboronando. No obstante, debería ser un requisito sine qua non que el Estado, al hacer un buen uso del derecho comparado, realice una calificación en la adaptabilidad de las instituciones jurídicas traídas de otro continente, aún más cuando con dicha implementación se abre paso a la graves consecuencias como la desigualdad e inseguridad entre las personas que utilizan la jurisdicción para satisfacer sus intereses.

En ese sentido, se realizará un análisis sistemático de las teorías planteadas en el texto Teoría impura del Derecho, en particular, respecto a las nociones jurídicas consideradas como "teorías transnacionales del Derecho (TTD)" y, en concreto, en lo que tiene que ver con la adopción del proceso monitorio en la modalidad de puro en el contexto jurídico nacional colombiano. A partir de ahí, se señalarán los fundamentos por los cuales no se adoptó como documental, pese a ser tendencia en los países latinoamericanos que comparten tradiciones jurídicas, sociales y económicas.

Es preciso determinar la diversidad de elementos y características del proceso monitorio para llegar a encontrar variables fundamentales que entran en juego a partir del trasplante jurídico que Colombia realizó en su ordenamiento interno. Las implicaciones de lo anterior son amplias en la medida en que la función del proceso monitorio puro puede llegar a ser mal interpretada cuando, por ejemplo, se da prevalencia al eficientísimo y a la celeridad del proceso y se sacrifican las

ROBLES, Gregorio. "Sociología de la decisión jurídica, 7.2 Sociología del proceso". En: Sociología del Derecho. Madrid (España): Editorial Civitas , 1997. pp. 20 - 23.

$8 \quad$ Ibidem.

9 LÓPEZ MEDINA. Op. cit. 
garantías que se desprenden del derecho fundamental al debido proceso al no contar con un principio de prueba por escrito, como ocurre con el tema de medidas cautelares que será estudiado más adelante.

Adicionalmente, es posible colegir que en la mayoría de los casos las instituciones jurídicas traídas del Derecho comparado pueden ser complejas si no se asimilan de acuerdo a la realidad propia de un orden nacional interno. Más aún, cuando países latinoamericanos acogen normas y teorías a partir del modelo que desarrollan otros países que tienen tradiciones jurídicamente consolidadas ${ }^{10} \mathrm{y}$ delinean un mismo esquema de implementación de la figura del proceso monitorio documental, lo cual resulta de vital importancia pues debe tenerse en cuenta la eficacia, la eficiencia (duración) y el estudio de los aspectos complejos, como las tradiciones socioculturales del Estado receptor, para su efectiva implementación ${ }^{11}$.

Los conceptos de eficiencia y eficacia adquieren especial relevancia en el contexto pues la primera, debe ser entendida como "el derecho al proceso" ${ }^{12}$, lo que se traduce en la instrumentalización e implementación de mecanismos que hacen prevalecer el debido proceso y sus componentes en el ordenamiento jurídico, además de tener una connotación sociológica al establecer que los procedimientos deben ser expeditos, accesibles y económicos para la solución de conflictos ${ }^{13}$. Lo anterior, en tanto que la eficacia del proceso retoma el pilar esencial que se materializa en el sentido de justicia, su transparencia y el derecho de acceder a esta como obligación a cargo del Estado, pues se trata de un derecho macro que corresponde a la función jurisdiccional ${ }^{14}$. Así mismo, es esencial notar que para llevarse a cabo la eficiencia procesal es necesario que haya una materialización de la justicia a la hora de mantener a flote el principio de una tutela judicial efectiva y esto sólo puede ser dado mediante la eficacia del proceso y su convergencia con el principio de eficiencia procesal.

10 DE SOUSA SANTOS, Boaventura; GARCÍA VILLEGAS, Mauricio, "El derecho y la comunidad: las transformaciones recientes de la naturaleza del poder del Estado en los países capitalistas avanzados, el derecho del estado capitalista". En: El caleidoscopio de las justicias en Colombia. “ Bogotá (Colombia): Editorial Uniandes, Siglo del hombre editores, 2001.

11 BOTERO BERNAL, Andrés. Diagnóstico de la eficacia del Derecho en Colombia y otros ensayos. Medellín: Señal Editora y Fondo Editorial Biogénesis, 2003.

12 GONZALES. Roberto. "El debido proceso: del derecho a las mínimas garantías a la garantía de máximos derechos". En: Revista Virtual Instituto Colombiano de Derecho Procesal. Edición 39, 2013. pp. 9 - 10.

13 BERIZONCE, Roberto. "El principio de legalidad formal bajo el prisma de la constitución 'normatizada". En: Revista Virtual Instituto Colombiano de Derecho Procesal, Edición 40, 2014. pp. 14.

14 PÉREZ, Álvaro. "Derecho a la tutela ejecutiva del crédito: entre mitos, temores y realidad”. En: Revista Virtual Instituto Colombiano de Derecho procesal. Edición 39, 2013. pp. 28. 
El proceso monitorio en Colombia: razones para una objeción

A su vez, resulta pertinente recordar que existen las denominadas "jurisdicciones prestigiosas"15, en las que se encuentra la base histórica, jurídica, social y económica del Derecho. Es de allí de donde surgen ideas y nociones originales de estos sistemas, que son retomadas por multiplicidad de ordenamientos internos. Bajo ese postulado, es posible catalogar a los países latinoamericanos como regiones ${ }^{16}$ o Estados receptores que, por ser países de economías emergentes carentes de rigidez y formación jurídica propia, acogen instituciones que por regla van a ser contaminadas e influenciadas, por lo cual, su implementación dejaría de ser pura para pasar por un proceso de transformación y mutabilidad ${ }^{17}$.

Por esto, al permitir que los operadores jurídicos del Estado receptor apliquen e interpreten los preceptos y nociones jurídicas trasplantadas, es posible que se generen prácticas que vayan en contravía con las necesidades y las características particulares del Estado que importa la institución, porque, como lo dice Victoria Iturralde: "la validez, radica en el problema de la aplicación del Derecho, este debe tener por objeto enunciados válidos que han sido creados por el legislador respetando requisitos del ordenamiento y que le son dados al juez; estableciendo así una división neta entre las funciones de creación y aplicación del derecho"18.

Adicionalmente, hay que establecer la interrelación que existe entre el trasplante del proceso monitorio puro en Colombia y su calidad como Estado receptor, para proceder con la crítica respecto de la adopción de dicho modelo, que rompe con el factor común implementado en Latinoamérica, el cual optó por exigir que para dar inicio al proceso monitorio la deuda debe constar por escrito. Por tanto, es pertinente en este punto cuestionar las razones que llevaron a nuestro país a implementarlo como no documental, sobre todo, al tener en cuenta que el documento se constituye como principio de prueba que permite dar mayor certeza a la pretensión del demandante en un proceso y que resulta ser tendencia marcada con amplia acogida en los países de tradición romano-germánica.

De lo anterior se resalta entonces que, si bien el proceso monitorio es un mecanismo célere $^{19}$, que agiliza el cobro de deudas, no se puede compensar la

15 Figuras parentales de las familias jurídicas (civil law and common law). LÓPEZ MEDINA. Op. cit. p. 480.

16 RODRÍGUEZ MARTÍNEZ, José Eduardo. Derecho, ciudad y sociedad - ensayo de sociología jurídica crítica. Editorial Centro de investigaciones socio jurídicas, Universidad Incca de Colombia, 2008.

17 GUILLÉN, Víctor Fairén. "Ensayo sobre la evolución del Derecho de Navarra: Desde la guerra de sucesión al Código Civil”. En: Príncipe de Viana. 6 (18), 1945. pp. 87-111.

18 ITURRALDE SESMA, Victoria. "Validez y existencia, concepto de validez". En: Aplicación del derecho y justificación de la decisión judicial. Valencia, España: Editorial Tirant lo Blanch, 2004.

19 BALBUENA TEBAR, Rafael. "Breves comentarios sobre el llamado proceso monitorio". En: Cuadernos de Estudios Empresariales, (9). 1999. p. 301. 
urgencia de la rapidez en la administración de justicia con el desconocimiento de principios y valores del ordenamiento jurídico, así como tampoco alterar el equilibrio de las partes que concurren al proceso ${ }^{20}$. Por eso debe hacerse un análisis desde la sociología jurídica para intentar determinar las raíces comunes de los países latinoamericanos, como son el colonialismo y la cultura jurídica de sus asociados, quienes tienen una marcada tendencia a no honrar sus compromisos cuando estos han sido adquiridos de manera informal.

\section{Estado del arte del proceso monitorio en los países latinoamericanos}

Para proceder con el debate, en esta parte del escrito es ineludible resaltar el desarrollo del proceso monitorio en el contexto latinoamericano, motivo por el cual se efectuará un análisis somero de la regulación que al respecto adoptaron Venezuela, Uruguay, Brasil, Costa Rica, Argentina, Ecuador y Bolivia, junto con el caso particular de España, para lograr evidenciar que la regla general que aplica al proceso monitorio en estos Estados es su adopción en la modalidad de documental. Vale aclarar que se estudian los países antes anotados porque, por ejemplo, Chile sólo adopta el monitorio en los procesos laborales, en tanto que Perú y Paraguay aún no lo contemplan en sus ordenamientos jurídicos.

\subsection{Venezuela}

En Venezuela al proceso monitorio se le denomina procedimiento por intimación, el cual ingresa al ordenamiento de ese país desde la entrada en vigencia del Código de Procedimiento Civil de $1990^{21}$, cuya pretensión principal es obtener el pago de una suma líquida de dinero o una cantidad cierta de cosas fungibles. Así mismo, en el artículo 643 del ya mencionado estatuto, se puede observar que este ordenamiento optó por el sistema documental y tiene como causal de inadmisión de la demanda el no acompañar la misma con un documento que pruebe el derecho que se alega, en el cual se demuestren los hechos constitutivos de la obligación ${ }^{22}$.

Igualmente, el artículo 644 del citado código consagra como documentos escritos suficientes para la admisión: "los instrumentos públicos, los instrumentos privados, las cartas, misivas, admisibles según el Código Civil, las facturas aceptadas, las letras de cambio, pagarés, cheques y cualesquiera otros documentos

\footnotetext{
20 Ibidem.

${ }^{21}$ REPÚBLICA BOLIVARIANA DE VENEZUELA. Congreso de la República de Venezuela, Código de Procedimiento Civil, 18 de septiembre de 1990.

22 ÁlvareZ, Tulio. Procesos Civiles Especiales Contenciosos. 2 Edición. Caracas: Universidad Católica Andrés Bello, 2008. pp. 177 - 190.
} 
El proceso monitorio en Colombia: razones para una objeción

negociables"23. Este aspecto quedó consagrado en la sentencia de 2008 del Tribunal Superior de Justicia, en la cual se establece claramente que una formalidad esencial para el procedimiento por intimación es el acompañamiento de un documento que pruebe la obligación, por lo que, al no haberse anexado ningún documento en el caso sometido al estudio de una corporación judicial, se consideró como una violación al proceso como instrumento fundamental para la realización de la justicia, el derecho a la defensa y la garantía del debido proceso $^{24}$.

\subsection{Uruguay}

El proceso monitorio en Uruguay data del antiguo Código de 1878 para la entrega de la cosa debida y la entrega efectiva de la herencia ${ }^{25}$. En 1988, entra en vigencia el actual Código General del Proceso y amplía los anteriores casos a: juicios ejecutivos, escrituración forzada, resolución de contrato de promesa, pacto comisorio, cesación de condominio de origen contractual, separación de cuerpos y de divorcio, entrega efectiva de la herencia y entrega de la $\operatorname{cosa}^{26}$.

Se puede observar que este país opta por el sistema documental, puesto que consagra cinco tipos de documentos conducentes para iniciar el proceso monitorio, entre los que se encuentran los documentos públicos y privados. En cuanto a estos últimos, es necesaria la firma reconocida ante tribunal competente o escribano, que debe verificar la autenticidad de la firma del deudor, con lo que se logra un mayor grado de certeza inicial. No obstante, se consagra la excepción al sistema documental y se establece que en caso de entrega de la cosa, para probar el contrato, se puede mediante prueba testimonial.

Además, el código establece que el juez debe verificar la demanda y sus presupuestos, la cual debe tener fehaciencia inicial, por lo que la probabilidad de oposición del contradictor es baja ${ }^{27}$. Al cumplir con tales requisitos, el juez dicta sentencia

23 REPÚBliCA BOLIVARIANA DE VENEZUELA. Congreso de la República de Venezuela, Código de Procedimiento Civil, 18 de septiembre de 1990.

24 RIVERA, Rodrigo. "El procedimiento por intimación". En: El procedimiento monitorio en América Latina: pasado, presente y futuro. 1 Edición. Bogotá: Editorial Temis, 2013. pp. 59 104.

25 LANDONI, Ángel. "El proceso por audiencias en el Código General del Proceso de Uruguay”. En: Biblioteca jurídica Virtual del Instituto de Investigaciones Jurídicas de la UNAM, 2013. Disponible en: http://biblio.juridicas.unam.mx/libros/7/3330/26.pdf [consultada el 21 de marzo de 2015].

26 URUGUAY. Senado y la Cámara de Representantes de la República Oriental del Uruguay. Código General del Proceso, 18 de octubre de 1988.

27 PEREIRA, Santiago. "Los procesos civiles por audiencias en Uruguay. 20 años de aplicación exitosa del Código Procesal Civil Modelo para Iberoamérica”. En: Revista Internacional de 
sobre el fondo del asunto y procede a citar al demandado para que pueda formular sus excepciones y, en caso de hacerlo, se convoca a una audiencia en donde se decidirá el litigio. Al mismo tiempo, y una vez verificada dicha fehaciencia, el juez, motu proprio, procede a decretar el embargo y, en caso de que el demandado no se oponga, tiene como consecuencia que tanto el embargo como la sentencia quedan en firme. Naturalmente, esta última hace tránsito a cosa juzgada y puede ejecutarse. Se destaca en el contexto uruguayo que en el $95 \%$ de los casos el demandado no se opone a la sentencia del proceso monitorio, razón que da lugar a la terminación del proceso ${ }^{28}$.

\subsection{Brasil}

Está consagrado el proceso monitorio desde 1995 con la Ley 9079, recibe el nombre de ação monitória y se puede promover para el reclamo de sumas de dinero o la entrega de una cosa determinada ${ }^{29}$. En cuanto el sistema se opta por el monitorio documental, puesto que se consagra en el artículo $1102^{\text {a }}$ que quien pretenda iniciar una acción monitoria debe acompañarla de una prueba escrita que no preste mérito ejecutivo, pero que sea capaz de infundir certeza razonable de la existencia de la obligación ${ }^{30}$.

Así mismo, en jurisprudencia del Superior Tribunal de Justiça de 2002 se estableció que esa prueba escrita puede no estar dirigida a probar directamente el hecho, sino a permitir que el juez, basado en las reglas del juicio y de la experiencia, deba presumir la voluntad del deudor de obligarse y aprobar así cualquier documento dirigido a promover la acción monitoria ${ }^{31}$. Finalmente, respecto a los documentos privados, no es necesario que estén autenticados (basta la simple copia $\left.^{32}\right)$. Es por esto que se evidencia la preferencia del legislador brasileño por un documento que, a pesar de no tener eficacia como título ejecutivo, permita

Estudios sobre Derecho Procesal y Arbitraje. No 2. 2009. Ministerio de ciencia y EducaciónGobierno de España. pp. 26 - 30.

28 Landoni. Op. cit.

29 BRASIL. Presidencia de la República, Código de Proceso Civil, 11 de enero de 1973.

30 MARQUÉS, Wilson. "A açãomonitória”. En: Revista da EMERJ. No 1. 1998. Scola Da Magistratura Do Estado Do Rio De Janeiro. pp. 88 - 99.

31 MARINONI, Luiz. "Reexame Da Prova Diante Dos Recursos Especial E Extraordinário". En: Revista Genesis de Direito Processual Civil. No 35. 2011. Conselho Federal da Ordem dos Advogados do Brasil. pp. 1 - 26.

32 GOMES, Jose. "A Prova Escrita Na Ação Monitória”. En: Revista Jurídica UNIGRAN. No 6. Centro Universitário da Grande Dourados, 2001. pp. 22 - 43. 
El proceso monitorio en Colombia: razones para una objeción

la identificación de un crédito, lo dote de valor probatorio y digno de fe como su autenticidad y evidencie así su eficacia ${ }^{33}$.

\subsection{Costa Rica}

Actualmente, en este país se encuentra regulado el proceso monitorio en el Código Procesal Civil y en la Ley de cobro judicial de 2007 y se permite tanto para obligaciones que presten mérito ejecutivo como para las que no cumplan este requisito. Para las obligaciones que no estén instrumentadas en un documento que preste mérito ejecutivo, el legislador fue claro en establecer el sistema documental, puesto que impone que se puede iniciar este proceso siempre y cuando al inicio del mismo se adjunte: "original, una copia firmada certificada cuando la ley lo autorice, o estar contenido en un soporte físico, en el que aparezca, como indubitable, quién es el deudor, la firma de este o la firma a ruego con dos testigos instrumentales o cualquier otra señal equivalente" 34 .

De lo anterior se puede observar que por regla general es necesaria la firma del deudor para que el documento sea idóneo y fehaciente con el fin de que no exista duda respecto de su calidad, además de que por sí mismo pueda demostrar la existencia de la obligación y evitar que los acreedores constituyan títulos unilateralmente. De igual forma, para que el deudor pueda formular con éxito la oposición debe aportar como prueba un documento idóneo y pertinente y consagrar cargas probatorias proporcionales para ambas partes. Al seguir con el proceso, en caso de que el demandado guarde silencio, se procederá con la ejecución de la deuda sin necesidad de iniciar un proceso ejecutivo posterior.

\subsection{Argentina}

Actualmente tres provincias de este país incluyen al proceso monitorio dentro de sus códigos procesales civiles y mercantiles. La primera provincia en incluirlo fue La Pampa en 1999, esta adoptó el modelo documental en el cual se prevé que "el actor deberá presentar instrumento público o instrumento privado reconocido judicialmente o cuya firma estuviere certificada por escribano público"35.

\footnotetext{
33 AYMAR, Renato. "A Ação Monitória Como Instrumento De Recuperação De Crédito Para As Empresas". En: Revista de Direito Privado E Processual Civil Comtemporâneo. No 1. 2010. Editora Revista dos Tribunais. pp. 1 - 12.

34 COSTA RICA. La Asamblea Legislativa de la República de Costa Rica, Ley de Cobro Judicial, 20 de noviembre de 2007.

35 PROVINCIA DE LA PAMPA. Cámara de Diputados, Código Procesal Civil y Comercial, 12 de marzo de 1999.
} 
A su vez, la provincia de Entre Ríos lo incluye en su código en el año 2006 con la misma regulación anterior, aunque le adiciona una diligencia previa en la que el actor podrá requerir al deudor para que reconozca el documento privado firmado. En caso de no comparecer a la cita, esta se tendrá como reconocida ${ }^{36}$.

Por último, la provincia de Río Negro en $2007^{37}$ y la provincia de San Juan en 2008 mantienen las reglas consagradas en el Código de La Pampa. No obstante, en el caso de Río Negro se prohíbe la oposición y se basa exclusivamente en testigos.

Se puede concluir que en el Estado argentino el sistema documental es el único adoptado y el documento que ha de presentarse con la demanda debe cumplir ciertos requisitos para que con éxito sirva de sustento y se pueda iniciar dicho proceso. Ejemplo de esto es la exigencia de reconocimiento de la firma del deudor por operadores judiciales o escribanos.

\subsection{Ecuador}

En el proyecto del Código Orgánico General de Procesos de este país se plantea incluir el proceso monitorio tomando como referencia la legislación uruguaya, en la cual el derecho que se pretende hacer valer tiene que estar dotado de un alto grado de certeza, por eso se estudia la inclusión del documental ${ }^{38}$. Por tanto, el artículo 376 de este proyecto consagra que puede ser cualquier documento, sin importar su forma, pero siempre y cuando tenga alguna señal de que proviene del deudor ya sea por firma física o firma electrónica.

Sin embargo, incluye como excepción que si no se tiene el documento como tal de la obligación que se pretende, se puede acompañar un documento que pruebe la existencia de una relación de acreedor-deudor entre las dos partes ${ }^{39}$.

\subsection{Bolivia}

El procedimiento monitorio hace su incursión en el ordenamiento boliviano en el artículo 375 del Código Procesal Civil de 2013, el cual dispone que el juez debe realizar un estudio previo en el que demuestre la fundabilidad de la pretensión para

36 PROVINCIA DE ENTRE RÍOS. Cámara de Diputados, Código Procesal Civil y Comercial, 20 de junio de 2007.

37 PROVINCIA DE RÍO NEGRO. Cámara de Diputados, Código Procesal Civil y Comercial, 5 de septiembre de 2011.

38 REPÚBLICA DE ECUADOR. Asamblea Nacional, Proyecto de Código Orgánico General de Procesos, 24 de julio de 2014.

39 REPÚBLICA DE ECUADOR. Asamblea Nacional, Proyecto de Código Orgánico General de Procesos, 24 de julio de 2014. 
que pueda acogerla mediante una sentencia inicial ${ }^{40}$. Por otra parte, el artículo 376 consagra específicamente los casos en los cuales se puede promover el procedimiento monitorio e incluye también a los procesos ejecutivos.

A su vez, la exposición de motivos del proyecto de ley señala que:

"Se ha optado por el monitorio documental y no por el monitorio puro, porque la orden de pago expresada en la sentencia inicial presupone que los hechos constitutivos del crédito están probados mediante documentos; y, en que mientras en el proceso monitorio puro la orden de pago pierde toda su eficacia por la simple oposición motivada del deudor, en el proceso monitorio documental la oposición del deudor no hace caer sin más el mandato de pago, pero tiene en cambio, el efecto de abrir un juicio de cognición en contradictorio $(\ldots)^{m+1}$.

De lo anterior se puede concluir que la preocupación del legislador boliviano era que el acreedor no perdiera su pretensión por la simple oposición del deudor, por el contrario, que con un documento sí se pudiera entrar en un juicio de contradicción y verificar si existe o no la obligación.

Adicionalmente, como requisito se debe acompañar documento auténtico o legalizado por autoridad competente y traer una excepción cuando se trate de desalojo en régimen de libre contratación o entrega del bien derivada de contrato verbal. Finalmente, dictada la sentencia el deudor puede oponerse y el artículo 381 taxativamente nomina las excepciones que se pueden formular, aunque si el demandado guarda silencio se procederá a la ejecución.

\subsection{El caso particular de España}

Debido al alto impacto que ha generado la inclusión del proceso monitorio documental en España, y al ser este modelo de implementación de ordenamientos internos de países latinoamericanos, no se puede desconocer su relevancia y por ello se procederá con su estudio particular.

El proceso monitorio se introduce por primera vez en España, con la Ley de Enjuiciamiento civil del año $2000^{42}$, para quien pretende el pago de una deuda dineraria vencida, exigible y determinada. En cuanto al sistema, se opta por el monitorio documental y, tal como se plasma en la exposición de motivos de esa ley,

40 BOLIVIA. Presidente Constitucional del Estado Plurinacional de Bolivia, Código Procesal Civil, 19 de noviembre de 2013.

41 BOLIVIA. Estado Plurinacional de Bolivia, Proyecto de Ley, Código Procesal Civil, Exposición de Motivos, 25 de abril de 2010.

42 ESPAÑA. Rey de España, Ley de Enjuiciamiento Civil, 8 de enero de 2000. 
es imperante el acompañamiento de un documento para que de ese mismo resulte una base de buena apariencia jurídica de la deuda ${ }^{43}$.

El artículo 812 establece que puede ser cualquier documento en clase y forma en donde se pueda encontrar que provenga del deudor y que acredite una relación entre las partes, así como el origen de la deuda. Cuando entró en vigencia la ley en 2001 estipulaba como cantidad máxima para acudir a un proceso monitorio 5.000 .000 de pesetas, cantidad que se convierte en 30.000 euros $^{44}$. No obstante en 2011 se elimina el límite cuantitativo para acudir a este proceso, con el objeto de equipararlo al monitorio europeo con el fin de evitar limitaciones de acceso a los acreedores ${ }^{45}$.

Al igual que en Colombia, el fin es pre-constituir el título ejecutivo ante el silencio del deudor tanto por no pagar como por no oponerse, en este caso termina el monitorio mediante el decreto del secretario judicial con el cual el acreedor podrá iniciar el proceso de ejecución. En caso de guardar silencio, el proceso monitorio finalizará y dará paso a un proceso declarativo en el que la cuantía de la obligación se tendrá en cuenta para la competencia ${ }^{46}$.

\section{El trasplante jurídico y aplicabilidad desde la sociología del proceso monitorio en Colombia}

Como se expuso, no es novedosa la implementación del proceso monitorio en el contexto latinoamericano, aunque sí lo es en el ordenamiento interno colombiano, por eso, al acudir a la teoría de los trasplantes jurídicos aplicada al caso concreto, se afirma que estos son utilizados con el fin de trasladar o transportar normas, instituciones y conceptos de un lugar a otro, es decir, de llevarlos de los sitios base de producción jurídica a los sitios base de recepción jurídica ${ }^{47}$. Sin embargo, tal situación no resulta foránea o excepcional pues se trata de un problema global y no meramente local que se traduce en la "información social de los contenidos de las normas"48.

43 ESPAÑA. Rey de España, Ley de Enjuiciamiento Civil: Exposición de Motivos, 8 de enero de 2000.

44 ESPAÑA. Vicepresidente segundo del Gobierno para asuntos económicos y Ministro de Economía y del Ministro de Justicia, Real Decreto 1417/2001, 27 de diciembre de 2001.

45 ESPAÑA. Rey de España, Ley de medidas de agilización procesal, 11 de octubre de 2011.

46 Portal Administración Justicia, “Guía Práctica del Procedimiento Monitorio". En: Secretaría General de la Administración de Justicia. Disponible en: https://www.administraciondejusticia.gob.es/paj/PA_WebApp_SGNTJ_NPAJ/descarga/guia\%20n\%C2\%BA1_monitorio. pdf?idFile=59ce256e-11b1-46d9-b870-3a93d4a65c66 [consultada el 21 de marzo de 2015].

47 LÓPEZ MEDINA. Op. cit. p. 8.

48 ROBLES, Gregorio. "Sociología formal del derecho, 10. Incertidumbre”. En: Sociología del derecho. Madrid (España): Civitas, 1997.

ISSN 2346-3473 • pp. 67-102 • Julio - Diciembre de 2016 • Bogotá, D.C. - Colombia 
El proceso monitorio en Colombia: razones para una objeción

Por otro lado, se hace indispensable evidenciar el papel relevante de la sociología jurídica pues regula las relaciones que existen entre las personas y el Estado, estudia "la eficacia y la función de instituciones que afectan directamente la vida de las personas" ${ }^{49} \mathrm{y}$, en el caso del proceso monitorio, permite determinar el fundamento de dicha institución que es el real y efectivo acceso a la justicia.

Es por eso que la institución del proceso monitorio debe correlativamente responder a las necesidades y realidades naturales del sistema colombiano, para que con su implementación se genere cierto grado de certeza y convicción ${ }^{50}$ de que la finalidad por la cual fue consagrado se cumpla. En ese sentido se afirma que es el modelo documental el que más se adapta a las necesidades internas y no el puro, que parte de la premisa en virtud de la cual, en caso de no contar con un documento que permita dar inicio al proceso, la demanda se soporte en una simple manifestación del demandante muchas veces incierta, general y abstracta. Lo anterior permite inferir que el legislador no realizó un estudio comparado pertinente de la aplicabilidad de las normas traídas al sistema de recepción colombiano pues, como se expone a lo largo del presente escrito, mutó la concepción inicial de modelo documental a puro, sin atender a razones acordes a la realidad material del país porque "el papel puede plasmar una cosa y en la realidad puede darse otra" ${ }^{51}$.

Como consideración adicional, en el texto La sociología del Derecho se plantean los denominados factores externos e internos ${ }^{52}$. Los primeros hacen referencia al acceso a la justicia (que resulta ser uno de los fines del proceso monitorio), aunque la variable prevalente al respecto es la desconfianza y la lejanía social con la administración de justicia. En el caso del proceso monitorio puro en Colombia, debe tenerse en cuenta que personas jurídicas como corporaciones o empresas de gran poder económico ${ }^{53}$ también podrían dar inicio a este proceso sin contar con soporte documental, pues no existe cualificación del demandante en el contexto del Código General del Proceso.

En ese orden de ideas, se requiere realizar una valoración en cuanto a qué tan eficaz puede llegar a ser la implementación del proceso monitorio puro respecto a su aplicación en la realidad social en Colombia, pues por regla general, las normas aplicables y el aparato estatal toman distancia de las necesidades sociales consideradas. Lo anterior genera un problema de inseguridad jurídica al tener en cuenta que el proceso monitorio se constituirá como el juicio estrella por la multiplicidad de relaciones jurídicas informales existentes en la actualidad nacional.

\footnotetext{
49 ROBLES. "Sociología de las instituciones jurídicas, 3. Investigación sociológica de las instituciones, 3.2. sociología del derecho privado". Op. cit.

50 GÓNGORA, Mario. Estado en el derecho indiano. Universitaria, 1951.

51 ROBLES. “Sociología formal del derecho, 10. Incertidumbre”. Op. cit.

52 ROBLES. "Sociología de la decisión jurídica, 7.2.3 barreras de acceso a la justicia”. Op. cit. 53 Ibidem
} 
Semillero de Derecho Procesal. Universidad del Rosario. Facultad de Jurisprudencia

\section{Particularidades procesales del proceso monitorio en Colombia}

En Colombia se decidió plantear esta novedad jurídica por medio del Proyecto de ley 196 de 2011, que desde el primer debate en Cámara tuvo como propósito "garantizar la efectividad de los principios, derechos y deberes consagrados en la Constitución (...) asegurar el derecho a un proceso de duración razonable y la tutela judicial efectiva" ${ }^{4}$. Lo anterior evidencia la preocupación del legislador por abarcar todas las aristas necesarias para alcanzar una administración de justicia de alta calidad.

En desarrollo de lo expuesto, el legislador se propuso realizar íntegramente dichas garantías a partir de prerrogativas como "el derecho a que existan procedimientos adecuados, idóneos y efectivos para la definición de las pretensiones y excepciones debatidas y el derecho a que los procesos se desarrollen en un término razonable, sin dilaciones injustificadas y con observancia de las garantías propias del debido proceso" ${ }^{55}$. En este sentido, el proceso monitorio se presenta como uno de los mecanismos más representativos en cuanto al logro de los fines a los que se refiere el Código General del Proceso.

De otra parte, una de las doctrinas que trabaja con mayor juicio el tema del proceso monitorio es la italiana, dada la tradición jurídica que esta figura representa para su sistema y dentro de ella. Se resalta la obra del jurista Piero Calamandrei, quien incluyó dentro de sus célebres estudios una clasificación sobre este procedimiento especial ${ }^{56}$ que se desarrolla a continuación: (i) El modelo puro, que se produce cuando no es preciso aportar junto a la demanda ninguna base documental y (ii) El modelo documental, que se caracteriza por la exigencia de un título documental, normalmente firmado por el deudor, que prima facie incorpore la existencia de una deuda ${ }^{57}$.

Dichas modalidades se adaptan a los respectivos ordenamientos con base en el contexto sociológico propio de cada uno de los sistemas jurídicos. Esto demuestra el hecho de que "los límites geográficos de estos dos grandes grupos de procesos monitorios coinciden prácticamente con la extensión territorial de las

54 COLOMBIA. Cámara de representantes. Primer Debate: Gaceta No. 250/11. Acta No. 061 de mayo 11 de 2011. Debate en Comisión, Acta No. 062, mayo 17 de 2011.

55 Ibidem.

56 NIEVA-FENOLL, Jordi; RIVERA, Rodrigo; COLMENARES, Carlos; CORREA, Juan. El procedimiento monitorio en América Latina: pasado, presente y futuro. 1 Edición. Bogotá: Editorial Temis, 2013. p. 40.

57 CALAMANDREI, Pietro. El procedimiento monitorio, colección clásicos del derecho. 1 Edición. Buenos Aires: Librería El Foro, 2006. p. 20.

ISSN 2346-3473 • pp. 67-102 • Julio - Diciembre de 2016 • Bogotá, D.C. - Colombia 
El proceso monitorio en Colombia: razones para una objeción

dos culturas más extendidas en nuestro Viejo Continente, es decir, la cultura latina y germánica"58. Así es como, mientras el proceso monitorio puro es aplicado por Alemania (\$\$688 a 703 d ZPO), Austria ( $\$ \$ 488$ y ss. ZPO), Portugal y parte de Suiza, el proceso monitorio documental se extiende por España (arts. 812 a 818 LEC), Italia (arts. 633 a 656 CPC) Francia (arts. 1405 a 1425 NCPC) y especialmente en la mayoría de países de América Latina ${ }^{59}$.

En el contexto colombiano, resulta interesante observar que desde que se planteó el proyecto de ley y hasta su aprobación en sesión plenaria de la Cámara de Representantes, el proceso monitorio se consagró bajo la modalidad documental, de ahí que el artículo 419 del proyecto de ley indicara que "la deuda se podrá acreditar con cualquier documento, sin importar su forma o el soporte en donde se encuentre, siempre que provenga del deudor y aparezca firmado por él, o con su sello o marca o, en general, con cualquier documento que haga razonable la probabilidad de la existencia de la obligación" ${ }^{60}$. No obstante, cuando se discutió en primer debate en el Senado de la República, se dispuso un proceso monitorio puro, que fue el acogido finalmente por el legislador al expedir la Ley 1564 de 2012.

Las disposiciones pertinentes a un proceso documental se suprimieron porque, de acuerdo con el senado, "a través del proceso monitorio puede llevarse a cabo de manera idónea la misma función que en la actualidad se cumple a través de otro tipo de procedimientos, como lo son el interrogatorio de parte solicitado como prueba anticipada, en el que se busca constituir un título ejecutivo a partir de

58 NIEVA-FENOLL, Jordi; RIVERA, Rodrigo; COLMENARES, Carlos; CORREA, Juan. El procedimiento monitorio en América Latina: pasado, presente y futuro. 1 Edición. Bogotá: Editorial Temis, 2013. p. 41.

59 NIEVA-FENOLL. Op. cit. p. 41.

60 Adicionalmente disponía "La deuda se podrá acreditar también con documentos que provengan del acreedor, como facturas, facsímiles, telegramas, y en general cualquier otro documento que habitualmente se acostumbre en las relaciones que se afirmen existentes entre deudor y acreedor, que permitan deducir con probabilidad que los documentos enunciados en el artículo anterior eran de utilización normal en la relación invocada”. El artículo 421 referido al trámite indicaba "si la demanda cumple los requisitos indicados en el artículo anterior, y si de lo relatado en ella y de los documentos que se acompañan, apreciados por el juez de conformidad con las reglas de la sana crítica, se concluye que existe un principio de existencia de la prueba, el juez ordenará requerir al deudor para que en el plazo de diez días realice el pago al acreedor, o comparezca y exponga por escrito las razones concretas que le sirven de sustento para negar total o parcialmente la existencia de la deuda reclamada". COLOMBIA. Cámara de representantes. Gaceta No. 995 de 2011 y Gaceta No. 822 de 2011. Texto definitivo aprobado en sesión plenaria al proyecto de ley 196 de 2011. Plenaria 094 del 18 de octubre de 2011. 
la confesión provocada de la contraparte" ${ }^{61}$. Es decir, en aras de no obstaculizar el acceso a la justicia se decidió suprimir aquellos formalismos que a juicio del legislador impedían vislumbrar las ventajas que representa el proceso monitorio frente a otras figuras procesales.

Sin embargo, aunque la elección del proceso monitorio en la modalidad de puro representa unos loables objetivos, hay que aterrizar dichos fines a la realidad para que no se turbe su aplicación, pues, como afirma Del Casso, el proceso monitorio no constituye de hecho más que una sutil adaptación del proceso ordinario a las necesidades prácticas del derecho material que se sustancia a través de sus cauces ${ }^{62}$. En tal virtud, resulta indispensable que el legislador revise el aspecto sociológico y material de la norma y, a partir de ahí, se analice el impacto práctico que tienen las disposiciones promulgadas.

Por otra parte, cabe la duda, al basarse en el artículo 420 del Código General del Proceso, de si el legislador, en un intento por no adoptar el modelo estrictamente puro, se inclinó por un modelo mixto al obligar al demandante a manifestar bajo juramento que no existen pruebas documentales de la obligación. No obstante, dicha exigencia no puede equipararse ni confundirse con la presentación de un documento fehaciente que cumpla con el principio de prueba de existencia. Lo anterior porque la mera manifestación del demandante, si bien es una formalidad, no conlleva en sí mismo valor probatorio, el cual, bajo la perspectiva ya estudiada en los demás países, lo da la importancia de presentar un documento que busca certeza y buena apariencia y evita dudas de la existencia del crédito. Por tanto, la manifestación juramentada de que no existen documentos no deja de ser unilateral ni cumple con la finalidad que busca el documento; en conclusión, no cambia la esencia de modelo puro, el cual se basa en el inicio del proceso monitorio con la sola afirmación.

En este orden de ideas, y de acuerdo a lo expuesto hasta el momento, se pueden realizar un par de conclusiones preliminares: en primer lugar, que Colombia es el único país latinoamericano que cuenta con el proceso monitorio puro (no mixto como algunos académicos sostienen) y, en segundo lugar, que la adopción de dicho modelo está fundamentada en un anhelo del legislador por traer al ámbito jurídico colombiano una figura que represente mayores ventajas que las ya consagradas por el Código de Procedimiento Civil. Sin embargo, es preciso entrar a revisar la importancia del soporte documental con el fin de demostrar las ventajas que dicha modalidad representa al ser una figura que se adecua mejor al ámbito colombiano y a su realidad jurídica.

${ }^{61}$ COLOMBIA. Senado de la República de Colombia, Primer debate Senado: Gaceta No. 114/12, abril de 2012.

62 NIEVA-FENOLL. Op. cit. p. 42. 
El proceso monitorio en Colombia: razones para una objeción

\section{La necesidad de aportar un principio de prueba documental en el proceso monitorio}

La existencia de un apoyo documental es necesaria e ineludible en la gran mayoría de procesos judiciales. Dicha premisa parte de un sustento lógico que refiere al documento como aquel medio "que garantiza la mayor fidelidad, que pueda quedar comprometida por la acción del tiempo sobre la memoria humana" ${ }^{63}$, lo cual permite que este medio de prueba se separe de influencias externas que podrían alterar su realidad. Para el caso en concreto de la aplicación del proceso monitorio en Colombia, habría sido una ventaja importante para el accionante el hecho de que cuente con un principio de prueba que permita identificar y verificar las posibles defraudaciones o corrupciones al sistema.

Otra de las virtudes del documento es que este supere los obstáculos de espacio y tiempo ${ }^{64}$, pues el medio documental tiene la capacidad de materializar un hecho de tal manera que pueda ser reconocido de forma objetiva por parte del observador con posterioridad. En este sentido, si se presenta una reclamación por parte del accionante, sólo se iniciará el proceso monitorio cuando la solicitud demuestre tener el mérito suficiente para mover el aparato judicial, lo cual permite la verificación de una situación fáctica concreta.

La existencia jurídica del documento se justifica en las funciones que desarrolla. La primera se refiere al carácter extraprocesal, de naturaleza sustancial y solemne y la segunda al carácter procesal y probatorio para la demostración de un hecho ${ }^{65}$. Por tanto, es necesaria su inclusión en el proceso monitorio al ser el medio por el cual se demostrará un elemento fáctico esencial consistente en la existencia de una obligación dineraria de carácter contractual insatisfecha por parte del deudor.

El proceso monitorio, en general, surge como una alternativa que le permite al ciudadano de a pie acceder a un proceso más ágil y eficaz que un proceso declarativo ordinario. No obstante, a partir del análisis sociológico referente al trasplante jurídico del proceso monitorio en Colombia, se determina que no es suficiente la simple afirmación del acreedor para empezar a desarrollar el iter procesal. Pues para obtener un resultado óptimo, es preciso contar con la "inicial garantía que aquellos documentos ofrecen acerca de la aparente existencia de un derecho de crédito" ${ }^{\prime 6}$.

${ }_{63}$ CARNELUTTI, Francesco. La prueba civil. 1 Edición. Buenos Aires: Ediciones Arayu, 1995. p. 121.

64 PARRA, Jairo. Tratado de la Prueba Judicial. Tomo III. 3 Edición. Bogotá: Librería del Profesional, 2003. p. 14.

65 PARRA, Jairo. Manual de Derecho Probatorio. 14 Edición. Bogotá: Librería Ediciones del Profesional, 2004. p. 538.

66 MONTERO, Juan. El Proceso Monitorio. Edición Séptima. Tomo II. España. Tirant Lo Blanch. 2012. Tema 38. p. 4. 
La idea principal es que se garanticen al individuo que quiere acceder a la administración los medios para hacerlo, siempre y cuando cuente con un principio de prueba que resulte razonable para poder incoar una reclamación. La base documental no requiere unas exigencias formales tan estrictas como las que plantea el actual artículo 488 del Código de Procedimiento Civil (CGP, art. 422), sino que se busca que su "incoación dependa de la presentación de un documento que ofrezca (...) una buena apariencia jurídica de la deuda" ${ }^{67}$, pues se refiere a los documentos cuyos "usos tienen aceptados como expresión ordinaria de deudas verdaderas, sin que su enunciado constituya una lista cerrada, sino abierta" ${ }^{\prime 6}$.

Es decir, que la persona del común tiene varias opciones para acceder a la administración de justicia. En un primer escenario, se puede plantear una situación en la cual la persona cuente con un documento, que por sus características encuadre en los requisitos que exige el ordenamiento procesal para conformar un título ejecutivo, caso en el cual puede iniciar un proceso ejecutivo por contar con un derecho, en principio, cierto e indiscutible. En un segundo escenario, se plantea la circunstancia por la que atraviesa un individuo que, si bien no tiene un título ejecutivo constituido, cuenta con alguna clase de documento que le brinde al juzgador una apariencia de deuda verdadera, caso en el cual podrá iniciar un proceso monitorio.

Este último enunciado cobra gran relevancia para la realidad colombiana y es preciso que el legislador lo tenga en cuenta, pues esto implicaría que el ciudadano pudiera presentar documentos que, aun cuando no tuvieran formalidad legal, se convierten en representaciones de la igualdad real de las partes que pregona el artículo $4^{\circ}$ del Código General del Proceso. Lo anterior, dado que se genera un mayor equilibrio entre demandante y demandado con el fin de lograr una mayor confianza en el sistema procesal por parte del Estado al verificar que no se está privilegiando a alguno de los extremos de la litis.

El proceso monitorio ha sido adoptado en los diferentes continentes porque su estructura posibilita un mayor alcance del poder jurisdiccional en la solución de controversias. No obstante, a nivel latinoamericano la modalidad de proceso con mayor éxito y acogida es el documental. Esto tiene una explicación en las especialísimas características que representan a los grupos sociales y, en el caso concreto, a la población colombiana, en la que un principio de prueba podría evitar defraudaciones por parte de los sujetos procesales. En ese sentido, dichos documentos podrían ser aceptados por parte del juez para iniciar el proceso monitorio siempre y cuando en él se logre determinar las características básicas que exige el artículo 419 y siguientes del Código General del Proceso. Es decir, que demuestren ser

\footnotetext{
67 MONTERO. Op. cit. p. 5.

68 Ibidem
} 
obligaciones contractuales de mínima cuantía, de carácter dinerario y que acrediten el vínculo jurídico entre acreedor y deudor.

Por otro lado, es importante tener presente que el legislador desde el primer debate en la Cámara se propuso desarrollar los mandamientos constitucionales que le imponen "garantizar a todos los asociados en condiciones de igualdad el derecho al debido proceso, el acceso a la administración de justicia y el cumplimiento estricto de los términos procesales, lo que equivale a asegurar el derecho a un proceso de duración razonable y la tutela judicial efectiva, en la forma contemplada en los instrumentos internacionales sobre derechos humanos que integran el bloque de constitucionalidad en virtud del mandato del artículo 93 de la misma obra"69. Es por esto que es importante resaltar que se presenta como fin el logro de la igualdad de las partes y es este un aspecto que a partir del ámbito probatorio logra garantizar el documento siempre y cuando genere las mismas cargas y prerrogativas para los sujetos procesales.

La igualdad, es uno de los preceptos con los que debe contar una sociedad que pretende alcanzar un orden social justo. Es por esto que la Carta Política colombiana de 1991 en su artículo 13 consagró dicho principio como uno de los elementos que conforman el denominado Estado Social de Derecho en los siguientes términos: “Todas las personas nacen libres e iguales ante la ley, recibirán la misma protección y trato de las autoridades y gozarán de los mismos derechos, libertades y oportunidades sin ninguna discriminación (...). El Estado promoverá las condiciones para que la igualdad sea real y efectiva".

Por ello, las diferentes ramas del Derecho deben seguir dicha directriz para que se respeten y se lleven a cabo los fines constitucionales. Por ejemplo, en el ámbito del Derecho Procesal, el Código General del Proceso en su artículo $4^{\circ}$ dispone que "El juez debe hacer uso de los poderes que este código le otorga para lograr la igualdad real de las partes", lo que se traduce en aterrizar la regulación procesal a la realidad del grueso de la población que acude ante la jurisdicción para que se logre una correcta administración de justicia.

En esa misma línea, la jurisprudencia de la Corte Constitucional se ha encargado de analizar las diferentes aristas de la igualdad y en uno de sus múltiples pronunciamientos señaló: "el principio de igualdad, se traduce en la garantía a que no se instauren excepciones o privilegios que exceptúen a unos individuos de lo que se concede a otros en idénticas circunstancias"70. En lo que respecta al proceso monitorio puro, es evidente el beneficio que se le da al demandante de poder demandar su causa sin algún soporte documental.

69 COLOMBIA. Cámara de Representantes, Primer debate Cámara: Gaceta No. 250/11. Acta No. 061 de mayo 11 de 2011. Debate en Comisión, Acta No. 062. Mayo de 2011.

70 COLOMBIA. Corte Constitucional. Sala Plena. Sentencia de Constitucionalidad. Junio 10 de 2003. M.P. Jaime Córdoba Triviño. 
La comisión redactora de la Ley 1564 del 2012 consideró la celeridad del proceso como la vía predilecta para lograr que el denominado ciudadano de a pie hiciera efectivo sus derechos. Es importante recalcar que en un principio saltan a la vista las ventajas de este aporte, pues es claro que el proceso monitorio puede constituir una herramienta importante para facilitar la tutela efectiva de los derechos por parte del Estado y el acceso a la justicia. No obstante, es aún más relevante tener claro que no siempre la obviedad nos lleva a resultados certeros en la práctica.

Es por esto que resulta fundamental evaluar todas las posibles aristas y variables que puedan intervenir en el desarrollo de los fines del proceso monitorio puro, pues es importante reconocer que se pueden tener los propósitos más loables pero, si no se tienen los instrumentos y mecanismos adecuados de interpretación, es probable que no se termine por respetar la naturaleza de las instituciones. En ese orden de ideas, el hecho de que el ordenamiento requiera un procedimiento célere no implica desconocer las bases constitucionales de igualdad y debido proceso que deben regir todas las actuaciones procesales.

\section{Medidas cautelares en el contexto del proceso monitorio en Colombia}

La institución jurídica de las medidas cautelares juega un papel fundamental en la implementación del proceso monitorio puro en Colombia por ser estas "un elemento integrante del derecho de todas las personas a acceder a la administración de justicia"11 bajo el carácter de petición accesoria que el demandante hace al juez en ejercicio del derecho de acción. El objetivo de lo anteriormente expresado es "asegurar el resultado final de un litigio en el supuesto de obtener una sentencia favorable a la pretensión demandada"72, garantizar la igualdad de las partes en el proceso y contribuir así a una justicia eficaz ${ }^{73}$, siempre que su aplicación resulte proporcional al caso concreto y al tipo de proceso en particular.

En ese sentido, el Código General del Proceso Colombiano plasma la intención del legislador de dar acogida a las cautelas en el contexto del proceso monitorio puro y rompe el esquema tradicional del modelo documental latinoamericano al establecer que "podrán practicarse las medidas cautelares previstas para los demás procesos declarativos" y que "dictada la sentencia en favor del acreedor, proceden

71 REPÚBLICA DE COLOMBIA. Corte Constitucional. Sentencia de inconstitucionalidad. C 490 de 2000. M. P.: Alejandro Martínez Caballero. Expediente D-2650.

72 ALVARADO, Adolfo. Las cautelas procesales. Crítica a las medidas precautorias. Facultad de jurisprudencia, Universidad Colegio Mayor de Nuestra Señora del Rosario. Editorial Universidad del Rosario, 2010. p. 29.

73 FORERO, Jorge. Medidas Cautelares en el Código General del proceso. 1ª Edición. Pontificia Universidad Javeriana: Editorial Temis, 2013. p. 1.

ISSN 2346-3473 • pp. 67-102 • Julio - Diciembre de 2016 • Bogotá, D.C. - Colombia 
El proceso monitorio en Colombia: razones para una objeción

las medidas cautelares propias de los procesos ejecutivos". De ahí que en el proceso monitorio en Colombia se dé aval a la posibilidad de solicitar medidas cautelares (incluso cuando no se tiene soporte documental) en dos sentidos: i) desde la formulación de la demanda proceden las medidas cautelares propias de los procesos declarativos (CGP, art. 590), y ii) que de haber sentencia favorable al acreedor, es viable solicitar el embargo y el secuestro como medidas cautelares de los procesos ejecutivos.

Al partir de la lectura de las normas colombianas, se afirma que el proceso monitorio puede iniciarse con una manifestación del demandante respecto de la existencia de una deuda dineraria porque se le otorga a esta un cierto grado de apariencia de certeza y se le da un reconocimiento de plena prueba. No obstante, debe tenerse en cuenta que "tanto el legislador como el juez, en el momento de ponderar la procedencia de las medidas cautelares, deben atender, no sólo a los criterios que de manera general se predican de todas ellas, sino también a la consideración del tipo de medida que resulte aplicable en cada caso" ${ }^{\prime 74}$ y en el proceso monitorio, que parte de la base de una declaración juramentada sin principio de prueba escrito en relación con el artículo 590 del Código General del Proceso, que consagra las medidas cautelares de los procesos declarativos, no es clara la eventual aplicación de las mismas por las incoherencias y restricciones con relación a dicho proceso.

Es ineludible resaltar el carácter conservativo de las medidas cautelares en un proceso, porque se protege el derecho correlativo que tiene todo acreedor a la ejecución forzada o coactiva frente al deudor incumplido con el propósito de impedir que en el patrimonio de este último se presenten modificaciones o mutaciones ${ }^{75}$. Lo anterior, "puesto que se trata de un efecto de la obligación civil, que no del título ejecutivo"76. Pero no se puede desconocer el hecho de que para materializar ese derecho sustancial, en el marco del proceso monitorio debería ser necesario aportar como principio de prueba un instrumento fehaciente ${ }^{77}$ que dé cuenta de que la obligación existe y que hay identidad de sujetos en lo que respecta al vínculo jurídico de la obligación dineraria para dar criterios objetivos de valoración y mayor apariencia de certeza a la pretensión. Esto porque con las cautelas eventualmente

74 REPÚBliCA DE COLOMBIA. Corte Constitucional. Sentencia de inconstitucionalidad. C 039 del 2004. M. P.: Rodrigo Escobar Gil. Expediente D-4664.

75 REPÚBLICA BOLIVARIANA DE VENEZUELA. Decisión No 2751 del Juzgado segundo de Primera Instancia en lo civil, mercantil, tránsito y bancario. Estado de Cojedes, 3 de noviembre de 2014 Que toma como referencia a VÁZQUEZ, Iván. Algunos secretos del procedimiento por intimación. 1995.

76 ÁlVAREZ, Marco. Ensayos sobre el Código General del proceso. 1 Edición. Editorial Temis, 2014. p. 5.

77 CALVINHO. Op. cit. p. 136. 
puede verse afectado el debido proceso y el derecho de defensa del demandado si su implementación no resulta proporcionada y razonable ${ }^{78}$.

Respecto de lo anterior, la jurisprudencia internacional de países como Venezuela y España evidencia que de no contar con un instrumento que acredite la existencia de la deuda se generan problemas de aplicación y de coherencia por la poca correspondencia entre las características y requisitos propios de las medidas cautelares de carácter patrimonial y las consecuencias que genera el decreto de las mismas en el marco del proceso monitorio. Por ello, en Venezuela la tendencia es que "la medida cautelar de este procedimiento es de carácter preventivo y provisional y su presupuesto de hecho directo es el tipo de documento que fundamenta la demanda"79, lo que, en otras palabras, implica que el presupuesto esencial de la concesión de las medidas cautelares es la presencia de un documento particularmente calificado por la ley ${ }^{80}$.

No obstante, es válido preguntarse ¿qué tan viable resulta el decreto de las medidas cautelares en el proceso monitorio cuando se soporta desde una declaración unilateral de parte? Si es evidente que dicho proceso adopta la modalidad de no documental, en principio, no es necesario aportar un instrumento o un principio de prueba que dé sustento efectivo de la obligación. Para la procedencia de las medidas cautelares, el juez debe atender a determinados presupuestos señalados por la doctrina y la jurisprudencia como son: la verosimilitud del derecho, fumus boni iuris, suspectio debitoris, periculum in mora y periculum in damni.

En ese orden de ideas, en el proceso monitorio puro, y cuando no se cuenta con un principio de prueba documental que justifique la apariencia de certeza mínima de la pretensión, se estarían generando problemas de coherencia entre las características propias de las medidas cautelares y la naturaleza del mencionado proceso. Esto es distinto a lo que ocurre en el modelo estrictamente documental porque muchas legislaciones, como la venezolana, encuentran la justificación de las cautelas en la existencia de un documento (que no un título ejecutivo).

De ahí que con ese principio de prueba escrito, la medida cautelar tendría mayor humo de buen derecho y posiblemente sí se cumpliría con la finalidad de esos instrumentos procesales que es asegurar o garantizar una obligación determinada de un acreedor que no cuenta con un título ejecutivo y elige recurrir a esta vía para satisfacer

78 REPÚBliCA DE COLOMBIA. Corte Constitucional. Sentencia de inconstitucionalidad. C 490 de 2000. M. P.: Alejandro Martínez Caballero. Expediente D-2650.

79 RePÚBliCA BOLIVARIANA DE VENEZUELA. Tribunal Supremo de Justicia, Sala de Casación civil. Sentencia del 26 de julio de 1989.

80 SÁNCHEZ, Abdón. Las medidas cautelares en el procedimiento por intimación. Anuario de la Facultad de Ciencias Jurídicas y Políticas de la Universidad de Los Andes. No 29. 2012. Centro de investigaciones jurídicas. Mérida. p. 22. 
El proceso monitorio en Colombia: razones para una objeción

su crédito. Esa es, precisamente, la gran diferencia entre un proceso monitorio, cuya demanda se sustenta en un documento, pues en ese caso sí se justificaría dar aval a las medidas cautelares porque se cumplen los presupuestos de las mismas (aunque en un mínimo sentido), y una demanda monitoria fundamentada en una simple declaración de la existencia incierta e infundada de una deuda constitutiva de una obligación dineraria, en la que se permitan las cautelas del 590 Código General del Proceso, pese a la contradicción de sus presupuestos con el proceso mismo.

$\mathrm{Al}$ atender a criterios de la lógica, es necesario advertir que si se armonizan los requisitos del decreto de las medidas cautelares patrimoniales con los requerimientos que exige el proceso monitorio en Colombia, existiría un desfase entre estas pretensiones accesorias y el proceso, cuando la parte no cuente con un documento y no se exija sustento probatorio diferente de una manifestación que acredite identidad de objeto, sujeto y causa de la obligación y que además pueda determinar de forma razonable que esta, en efecto, se hizo exigible en la demanda. Lo que en este caso atiende a criterios "pro-acreedor", en detrimento del extremo pasivo de la litis y de las garantías procesales propias que se desprenden del debido proceso.

Así, por ejemplo, el hecho de privilegiar el acceso a la justicia de una persona que tiene un crédito informal, al tener en cuenta que la función del proceso monitorio es pre-constituir un título ejecutivo por la vía de un procedimiento célere, hace evidente una oda al "eficientismo" en aras de lograr metas en corto plazo, que sacrifican correlativamente derechos y garantías de valor superior. Por eso, debe dársele un tratamiento distinto a la viabilidad de las medidas cautelares en el proceso monitorio documental (en el que eventualmente sí sería viable su decreto) y a la consecuente improcedibilidad de las mismas en el ámbito del proceso monitorio rigurosamente puro, por las incoherencias que se presentan en el análisis de ambas instituciones jurídicas.

Consecuentemente con lo dicho, en el caso colombiano un proceso declarativo por regla general parte de la base de que el derecho es incierto y discutible, pero al tratarse del proceso monitorio, nacido de una declaración juramentada, de una u otra forma se le está atribuyendo un cierto grado de certeza (tinte de proceso ejecutivo) a una simple afirmación hecha por el acreedor en el caso de que no cuente con prueba documental alguna que le otorgue respaldo y sustento a su pretensión. Además, se le da vía libre a la solicitud de las medidas cautelares propias de los declarativos desde la formulación de la demanda y se refuerza la aplicación de las mismas cuando se hubiere obtenido sentencia favorable al demandante con la posibilidad de invocar las medidas cautelares propias de un proceso ejecutivo, lo cual resulta desproporcionado frente a la ausencia de un instrumento fehaciente ${ }^{81}$

$81 \quad$ Hernández, Gabriel. La reforma al proceso ejecutivo: estudio del impacto que sobre este tiene el análisis económico del Derecho. Editorial Universidad del Rosario- Facultad de jurisprudencia. 2014. pp. 36-37. 
que acredite la deuda cuando en determinada situación se admita la demanda a partir de la afirmación del acreedor-demandante.

Como criterio adicional, es posible deducir que resulta lesivo el decreto de las cautelas al inicio del proceso monitorio sin sustento documental. Las principales razones son: el hecho de que se rompe la imparcialidad del juez cuando no existen criterios objetivos de valoración en el evento en que el proceso se inicie sin anexar como prueba un instrumento que justifique su viabilidad y una "manifestación" no bastaría para acreditar la existencia de la obligación y la identidad de sujetos inmersos en los extremos de la litis y porque es el mismo juez quien va a constituir el título ejecutivo con declaración de parte que puede considerar como aparentemente cierta o no.

El interrogante en este punto recae en si se vulnera o no el derecho a la igualdad de las partes cuando sea posible solicitar medidas cautelares en un proceso que se inicia con una simple afirmación del acreedor y en el que, además, frente a la falta de oposición del demandado, estas sean materializadas, porque con el proceso monitorio se está anticipando el contenido de la sentencia si el demandado no concurre al proceso, pues se constituiría el título ejecutivo y el proceso mutaría su cauce.

Adicionalmente, en lo que a la inversión del contradictorio respecta, es al deudor a quien le corresponde controvertir la manifestación inicial del demandante "con explicación de las razones por las cuales considera no deber en todo o en parte, para lo cual deberá aportar las pruebas en que se sustenta su oposición" 82 . Es innegable la dificultad probatoria que sobre el demandado recae y que debe asumir si pretende obtener sentencia favorable en el proceso, lo cual resulta contrario a toda lógica porque, por regla, en un proceso declarativo es el acreedor quien tiene la carga de la prueba y está interesado en salvaguardar su crédito y asegurar su efectivo cumplimiento.

Consecuentemente con lo dicho, lo que se analizará a continuación son los postulados doctrinales sobre los presupuestos de toda cautela, "que deben concurrir contemporánea y sucesivamente para que cualquiera de ellas tenga eficacia y su resultado sea eficiente". Estos deben ser ponderados por el juez cuando va a otorgar las medidas cautelares en el marco del proceso monitorio: verosimilitud del derecho o fumus boni iuris, suspectio debitoris, periculum in mora y periculum in damni.

En ese orden de ideas, "es verosímil lo que tiene apariencia de ser verdadero y resulta creíble" ${ }^{\prime 3}$, bajo ese entendido, y en atención a la naturaleza del proceso monitorio, lo que se pretende con la cautela es preservar la ejecución de un derecho incierto, pero no resulta razonable, que haya lugar al decreto de las mismas cuando

82 REPÚBLICA DE COLOMBIA. Ley 1564 de 2012 .Código General del Proceso, artículo 421, inciso 4.

83 ALVARADO. Op. cit. p. 47. 
El proceso monitorio en Colombia: razones para una objeción

no hay un principio de prueba que acredite dicha situación jurídica. A su vez, cuando la manifestación que el demandante hace bajo juramento constituye plena prueba (porque el fundamento de la acción parte de un supuesto cierto o no, que realiza un sujeto que afirma ser acreedor de una obligación dineraria de carácter contractual), se permite un criterio interpretativo extenso e ilimitado al juez, porque se otorgará la cautela según lo que este último cree y "acepta subjetivamente" ${ }^{84}$ como verdad aparente. Lo anterior conculca las garantías procesales del demandado, en la medida en que no se estará asegurando la imparcialidad del juez.

En lo que al peligro en la demora respecta, es necesario que se "afirme y se acredite inicialmente por el cautelante la existencia de urgencia en la obtención de la cautela, pues se corre un grave peligro de que la demora frustre el derecho litigioso" ${ }^{\prime 5}$, lo que aparentemente no cuadra con la finalidad del proceso monitorio, ya que se supone que por su naturaleza célere tendría que evacuarse en un lapso breve y razonable.

Ahora, y tratándose del denominado periculum in damni que "se exige en función de la finalidad anticipatoria que puede cumplir la medida innovativa, y consiste en establecer los daños que se producirían si no se otorgara la medida total o parcialmente" ${ }^{\prime 6}$, es viable resaltar que en Colombia existen varios factores "atenuantes" a la premisa al hablar del proceso monitorio, en el caso de que no se aporte documento como sustento de las pretensiones: 1) Es de mínima cuantía (Máx. 40 SMLMV). 2) Es de breve duración (en principio, no tendría por qué verse lesionado el interés económico del demandante por ese motivo). 3) Existiría una desproporción entre la concesión de la cautela a partir de una manifestación unilateral y el derecho fundamental al debido proceso y la igualdad de las partes, por la dificultad probatoria para el demandado de controvertir dicha afirmación, por lo cual este debe "aportar pruebas en que se sustenta su oposición" ${ }^{\prime 7}$.

Para proseguir con el debate, del hecho de no contar con un principio de prueba documental surgen problemas de viabilidad y de aplicación de los parámetros establecidos en el artículo 590 del Código General del Proceso sobre medidas cautelares y el proceso monitorio puro, por lo cual es posible colegir que desde la formulación de la demanda:

$84 \quad$ Ibidem.

85 Ibidem.

86 AGUIRRÉZABAL GRÜNSTEIN, Maite. "Comentarios de Jurisprudencia- Derecho procesal". En: Revista Derecho SCielo. Versión On-line ISSN 0718-8072. RChDP no.21 Santiago diciembre de 2013. Disponible en: http://dx.doi.org/10.4067/S0718-80722013000200021

87 REPÚBliCA DE COLOMBIA. Congreso de la República, Ley 1564 de 2012. Julio de 2012. Código General del Proceso, artículo 421. Título III. Cap. IV. Procesos declarativos especiales. Proceso monitorio- Trámite: "Si dentro de la oportunidad señalada en el inciso primero el demandado contesta con explicación de las razones por las que considera no deber en todo o en parte, para lo cual deberá aportar las pruebas en que se sustenta su oposición". 
Semillero de Derecho Procesal. Universidad del Rosario. Facultad de Jurisprudencia

i) No procederá la inscripción de la demanda porque esta versa únicamente sobre bienes sujetos a registro y tampoco aplicará el secuestro de bienes, porque el presupuesto para una u otra medida es que "la demanda verse sobre derecho real de dominio u otro derecho real principal" ${ }^{\prime 8}$ y el proceso monitorio en Colombia parte de la base de la existencia de un derecho personal correspondiente a un crédito.

ii) No resultará viable la inscripción de la demanda sobre bienes de propiedad del demandado en procesos de responsabilidad civil extracontractual ni contractual (para el caso), cuando se acumule una pretensión de condena inherente al pago de perjuicios, porque el proceso monitorio en el contexto nacional exige que la obligación dineraria de carácter contractual sea "determinada y exigible" Además, para solicitar indemnización de perjuicios se debe acudir a la figura del juramento estimatorio que señala que "quien pretenda el pago de una indemnización (...) deberá estimarlo razonadamente bajo juramento en la demanda". Lo anterior rompe con el esquema planteado para el proceso monitorio, que es que la deuda sea "determinada", y una estimación razonada no ostenta dicha connotación ${ }^{90}$.

iii) Finalmente, respecto de la medida cautelar genérica o innominada, se señala que su carácter es residual en relación a las otras cautelas, sin embargo, no es clara su aplicación cuando en el proceso monitorio puro es el acreedor quien solicita la medida que considera útil, proporcional y necesaria para asegurar su derecho. Además, provee al juez con "un amplio margen de discrecionalidad para decidir sobre esas medidas" ${ }^{\prime 1}$. Se destaca esta última afirmación, porque en ese contexto el director del proceso no tendría ningún criterio objetivo de análisis de la medida, lo cual evidencia un exceso de potestades en cabeza de aquel, en detrimento del debido proceso ${ }^{92}$ y su previsión terminaría siendo inane ${ }^{93}$.

88 REPÚBLICA DE COLOMBIA. Congreso de la República, Ley 1564 de 2012. Julio de 2012. Código General del Proceso, artículo 590. Título I. Cap. I. Medidas cautelares en procesos declarativos.

89 REPÚBLICA DE COLOMBIA. Congreso de la República, Ley 1564 de 2012. Julio de 2012. Código General del Proceso, artículo 419. Título III. Cap. IV. Procesos declarativos especiales. Proceso monitorio.

$90 \quad$ HERNÁNDEZ. Op. cit. pp. 40 - 41.

91 VILLAMIL, Edgardo. Memorias del XXXIII Congreso Colombiano de Derecho Procesal. ISSN 2322-6560. Primera edición. Bogotá Colombia: Universidad Libre Bogotá D.C., 2012. p. 175.

$92 \mathrm{Al}$ respecto, la doctrina internacional ha señalado que no procede la medida cautelar innominada, pero atiende más a criterios de taxatividad de las medidas cautelares y a la normativa interna propia de cada Estado. (Ver artículo sobre el proceso por intimación en Venezuela).

93 HERNÁNDEZ. Op. cit. pp. 40 - 41. 
El proceso monitorio en Colombia: razones para una objeción

De lo anterior es posible afirmar que al tratarse de la medida cautelar genérica el criterio de imparcialidad del juez quedará en entredicho cuando este último la decrete a partir de una "manifestación clara y precisa de que el pago de la suma adeudada no depende del cumplimiento de una contraprestación a cargo del acreedor" ${ }^{\prime 94}$, porque el demandante resultará beneficiado, en detrimento del supuesto deudor y correlativamente se le atribuirá a mencionados instrumentos procesales una aplicación irrazonable e injustificada desde la formulación de la demanda en el juicio monitorio ${ }^{95}$.

Respecto del tema de las medidas cautelares, la propuesta principal es que no sea posible su aplicación en el ámbito del proceso monitorio, que parte de una declaración juramentada de parte (modelo puro), por las incoherencias existentes entre las dos instituciones jurídicas y porque sería nocivo en lo referente a las garantías que se desprenden del derecho fundamental al debido proceso contenido en la Carta Política colombiana. No obstante, de no ser posible la materialización de la propuesta inicial, la premisa debería ser que la aplicación de dichos instrumentos procesales sea posible únicamente en el contexto del proceso monitorio estrictamente documental, como las reglas de la experiencia latinoamericana indican.

Por otro lado, en lo que se refiere al análisis de la procedencia cautelar, es preciso indicar algunos aspectos que diferencian la prueba documental y el juramento por ausencia de dicha prueba:

i) La practicidad en la evaluación probatoria por parte del juez: la prueba documental, en su aspecto práctico, "funciona sin mayores contratiempos, a pesar de que ciertos aspectos en particular, como la falsedad del documento o la aportación de los mismos, pueden ser objeto de revisión con el propósito de favorecer la agilidad"96. Mientras que la simple manifestación del demandante, propuesta por la Ley 1564 de 2012 del Código General del Proceso, genera al evaluador judicial revisión de otros medios probatorios que certifiquen su veracidad, toda vez que su sustento puede llegar a ser meramente subjetivo.

94 REPÚBLICA DE COLOMBIA. Congreso de la República, Ley 1564 de 2012. Julio de 2012. Código General del Proceso, artículo 419 \#5.

95 HERNÁNDEZ, Gabriel. Jurisdicción y competencia: funcionas jurisdiccionales de las autoridades administrativas. En: Ley 1564 de 2012 comentada con artículos explicativos de miembros del ICDP. Bogotá, 2014. p. 217. Ahora, el sustento jurisprudencial de dicha afirmación se solidifica con la sentencia de la Corte Constitucional Colombiana, C-835 de 2013, en la que se declaró la inconstitucionalidad de que una autoridad administrativa pudiere decretar "cualquier otra medida que encuentre razonable para garantizar el ejercicio de las funciones de inspección vigilancia y control", al referirse a la medida cautelar innominada.

96 ROJAS, Sergio. La prueba como aspecto de necesaria consideración para hacer de la oralidad una realidad material en el proceso civil. Instituto de Derecho Procesal Colombiano - ICDP. Fecha de recepción: 21 de noviembre de 2010. 
ii) El momento de su creación: la prueba documental se genera, por lo general, simultánea al momento en que se contrae la deuda, mientras que la simple manifestación del demandante es posterior al hecho cuya veracidad se discute.

En este sentido, el documento, al consagrar el hecho a probar con mayor proximidad que el juramento, resulta un elemento probatorio más preciso, teniendo en cuenta que su origen es anterior al conflicto.

iii) La objetividad: el documento sirve para dejar constancia de un hecho, sin tener en cuenta puntos de vista de las partes que podrían distorsionar lo ocurrido.

De conformidad con lo anterior, se observa que la prueba documental ofrece mayores facilidades y ventajas prácticas que la simple manifestación del demandante. Así las cosas, el juramento propuesto como prueba en ausencia de la prueba documental podría generar más dificultades y tropiezos al proceso monitorio que ventajas.

\section{Conclusiones}

1. El proceso monitorio se constituye como institución jurídica estrella en el contexto global por su contribución a la celeridad de las actuaciones judiciales y la materialización del derecho a la tutela efectiva del crédito de quienes son acreedores de obligaciones informales.

2. En Latinoamérica, y en general en los países cuya tradición jurídica es el civil law, han optado por el proceso monitorio documental por ser garantía de seguridad jurídica y por permitir la implementación de otras instituciones relevantes en lo que al Derecho procesal respecta como lo son las medidas cautelares.

3. El legislador colombiano optó por dar acogida al proceso monitorio puro, aunque muchos académicos lo denominan modelo "mixto" porque pretenden abarcar lo mejor de los dos sistemas, al tener en cuenta que existen figuras, como el interrogatorio de parte como prueba anticipada, que suplen la falta de un principio de prueba documental y de esa manera imponen formalismos adicionales al mencionado procedimiento declarativo especial.

4. Es necesario un alto grado de certeza, fehaciencia y buena apariencia jurídica del derecho que se pretende hacer valer para poder promover un proceso monitorio, por eso es de suma importancia el aporte de un documento en el que se pueda inducir dicho derecho.

5. Tener como requisito un principio de prueba por escrito para dar inicio al proceso monitorio da lugar a que la probabilidad de oposición del deudor sea baja, con base en la alta certeza el derecho pretendido.

6. El proceso monitorio estrictamente documental atiende más a las necesidades propias del contexto nacional colombiano, en la medida en que es peligroso 
El proceso monitorio en Colombia: razones para una objeción

que se pueda formular la demanda y solicitar medidas cautelares a partir de una simple manifestación de un aparente acreedor de una deuda dineraria, de carácter contractual y de mínima cuantía.

7. Las normas deben ser creadas con base en su destinatario. En el caso particular de Colombia, con la implementación del proceso monitorio debió haberse ponderado el derecho de los acreedores a tener un real y efectivo acceso a la justicia con el derecho de oposición que tiene todo demandado dentro del proceso y, en general, con las garantías que se desprenden del derecho fundamental al debido proceso.

8. En Colombia, el proceso monitorio será un mecanismo célere que agilice el cobro de deudas, pero no se puede compensar la urgencia de la rapidez en la administración de justicia con el desconocimiento de principios y valores del ordenamiento jurídico, así como tampoco irrumpir con el equilibrio de las partes que concurren al proceso.

9. La defensa del proceso monitorio documental en Colombia halla su fundamento en los trasplantes jurídicos de la figura que demarcan la regla general en los países latinoamericanos, esta es la de acoger en sus ordenamientos jurídicos internos la necesidad de apariencia de la existencia de la deuda con un principio de prueba por escrito para poder dar inicio al proceso.

10. El estudio de Derecho comparado de la institución jurídica del proceso monitorio en los países latinoamericanos, y en el caso particular de España, permite colegir que el proceso monitorio rigurosamente documental puede tener diferentes variaciones, pues unos países sólo admiten la figura para el pago de deudas dinerarias, en tanto que otros lo conciben también para la entrega efectiva de bienes, unos optan por limitar su cuantía, mientras que otros le dan aval a la posibilidad de ventilar asuntos de cualquier monto por la vía de dicho proceso.

11. Colombia es el único país latinoamericano que adoptó el proceso monitorio puro y no el estrictamente documental. El fundamento de su implementación halla su origen en un anhelo del legislador por traer al ámbito jurídico interno una figura novedosa que permitiera el real y efectivo acceso a la justicia, sin embargo, es un asunto que deja de lado la realidad fáctica nacional y el buen desarrollo del proceso en su modalidad de documental en los países que así lo concibieron.

12. El tema de las medidas cautelares resulta ser de especial relevancia, ya que la naturaleza jurídica de las mismas se opone a la del proceso monitorio puro, pues los presupuestos de unas y otro entran en contradicción al no ser posible el cumplimiento de los requisitos propios de aquellos instrumentos procesales accesorios como el fumus boni iuris, suspectio debitoris y periculum in mora.

13. Respecto del tema de las medidas cautelares, la propuesta es que no sea posible su aplicación en el ámbito del proceso monitorio que se inicie sin la exigencia 
Semillero de Derecho Procesal. Universidad del Rosario. Facultad de Jurisprudencia

de un documento fehaciente. Sin embargo, sería viable la aplicación de dichos instrumentos procesales únicamente en el contexto del proceso monitorio estrictamente documental.

\section{Referencias Bibliográficas}

\section{Libros}

ALVARADO. Adolfo. Las cautelas procesales. Crítica a las medidas precautorias. Facultad de jurisprudencia, Universidad Colegio Mayor de Nuestra Señora del Rosario. Editorial Universidad del Rosario, 2010.

ÁLVAREZ, Marco. Ensayos sobre el Código General del proceso. 1 Edición. Editorial Temis, 2014.

ÁLVAREZ, Tulio. Procesos civiles especiales contenciosos. 2 Edición. Caracas: Universidad Católica Andrés Bello, 2008.

BOTERO, Andrés. Diagnóstico de la eficacia del Derecho en Colombia y otros ensayos. 1 Edición. Medellín: Señal Editora y Fondo Editorial Biogénesis, 2003.

CALVINHO, Gustavo. Debido proceso y procedimiento monitorio. VV.AA, Director. Alvarado Velloso - Zorzoli, Ediar, 2006.

CARNELUTTI, Francesco. La prueba civil. 1 Edición. Buenos Aires: Ediciones Arayu, 1995.

DE SOUSA, Boaventura; GARCÍA, Mauricio, El caleidoscopio de las justicias en Colombia. Bogotá: Ediciones Uniandes, Siglo del hombre Editores, 2001.

FORERO, Jorge. Medidas Cautelares en el Código General del proceso. 1 Edición. Pontificia Universidad Javeriana. Editorial Temis, 2013.

GARCÍA, Mauricio. Normas de papel: la cultura del incumplimiento de reglas. 1 Edición. Bogotá: Siglo del hombre, 2009.

HERNÁNDEZ, Gabriel. La reforma al proceso ejecutivo: estudio del impacto que sobre este tiene el análisis económico del Derecho. Editorial Universidad del Rosario Facultad de jurisprudencia, 2014.

ITURRALDE, Victoria. "Validez y existencia". En: Aplicación del derecho y justificación de la decisión judicial. 1 Edición. Valencia: Tirant lo Blanch, 2004.

LÓPEZ, Diego. Teoría impura del derecho - la transformación de la cultura jurídica latinoamericana. 1 Edición. Bogotá: Legis, 2004.

MONTERO, Juan. El proceso monitorio. Tema 38. Edición séptima. Tomo II. España: Tirant Lo Blanch, 2012. 
El proceso monitorio en Colombia: razones para una objeción

NIEVA - FENOLL, Jordi; RIVERA, Rodrigo; COLMENARES, Carlos; CORREA, Juan. El procedimiento monitorio en América Latina: pasado, presente y futuro. 1 Edición. Bogotá: Editorial Temis, 2013.

PARRA, Jairo. Tratado de la Prueba Judicial. Tomo III. 3 Edición. Bogotá: Librería del Profesional, 2003.

PARRA, Jairo Manual de Derecho Probatorio. 14 Edición. Bogotá: Librería Ediciones del Profesional, 2004.

QUINTERO PÉREZ, Magda; BONETT ORTIZ, Samir. "El proceso monitorio: tendencia del Derecho procesal iberoamericano". Ponencia en el Concurso para abogados en el marco de las XXIV Jornadas Iberoamericanas de Derecho Procesal, organizadas por el Instituto Iberoamericano de Derecho Procesal y el Instituto Colombo Panameño de Derecho Procesal, en Ciudad de Panamá, el 26, 27 y 28 de marzo de 2014.

RIVERA, Rodrigo. "El procedimiento por intimación”. En: El procedimiento monitorio en América Latina: pasado, presente y futuro. 1 Edición. Bogotá: Editorial Temis, 2013.

ROBLES, Gregorio. "Sociología de la decisión jurídica”. En: Sociología del derecho. 1 Edición. Madrid: Editorial Civitas, 1997.

RODRÍGUEZ, José. Derecho, ciudad y sociedad - ensayo de sociología jurídica crítica. Bogotá: Centro de investigaciones socio jurídicas Universidad Incca de Colombia, 2008.

RUIZ, Ethelia. Gobierno y sociedad en Nueva España: segunda audiencia y Antonio de Mendoza. 1 Edición. Zamora de Hidalgo. El Colegio de Michoacán A.C. 1991.

VILLAMIL Edgardo. Memorias del XXXIII Congreso Colombiano de Derecho Procesal, ISSN 2322-6560. Primera edición. Bogotá: Universidad Libre Bogotá, 2012.

YUNIS, Emilio. ¿Por qué somos así?: ¿Qué pasó en Colombia? Análisis del Mestizaje. 1 Edición. Bogotá: Editorial Temis, 2003.

\section{Leyes y jurisprudencia}

BOLIVIA. Estado Plurinacional de Bolivia, Proyecto de Ley "Código Procesal Civil”. Exposición de Motivos, 25 de abril de 2010.

BOLIVIA. Presidente Constitucional del Estado Plurinacional de Bolivia, Código Procesal Civil, 19 de noviembre de 2013.

BRASIL. Presidencia de la República Código de Procesos Civiles, 11 de enero de 1973.

COSTA RICA. La Asamblea Legislativa de la República de Costa Rica, Ley de Cobro Judicial, 20 de noviembre de 2007. 
Semillero de Derecho Procesal. Universidad del Rosario. Facultad de Jurisprudencia

ESPAÑA. Rey de España, Ley de Enjuiciamiento Civil, 8 de enero de 2000.

ESPAÑA. Rey de España, Ley de Enjuiciamiento Civil: Exposición de Motivos, 8 de enero de 2000.

ESPAÑA. Vicepresidente Segundo del Gobierno para Asuntos Económicos y Ministro de Economía y del Ministro de Justicia, Real Decreto 1417/2001, 27 de diciembre de 2001.

ESPAÑA. Rey de España, Ley de Medidas de Agilización Procesal, 11 de octubre de 2011.

PROVINCIA DE ENTRE RÍOS. Cámara de Diputados, Código Procesal Civil y Comercial, 20 de junio de 2007.

PROVINCIA DE LA PAMPA. Cámara de Diputados, Código Procesal Civil y Comercial, 12 de marzo de 1999.

PROVINCIA DE RÍO NEGRO. Cámara de Diputados, Código Procesal Civil y Comercial, 5 de septiembre de 2011.

REPÚBLICA BOLIVARIANA DE VENEZUELA. Tribunal Supremo De Justicia, Sala de Casación Civil. Sentencia del 26 de julio de 1989.

REPÚBLICA BOLIVARIANA DE VENEZUELA. Congreso de la República de Venezuela, Código de Procedimiento Civil, 18 de septiembre de 1990.

REPÚBLICA DE COLOMBIA. Cámara de representantes. Primer Debate: Gaceta No. 250/11. Acta No. 061 de mayo 11 de 2011. Debate en Comisión, Acta No. 062, mayo 17 de 2011.

REPÚBLICA DE COLOMBIA. Senado de la República de Colombia, Primer debate Senado: Gaceta No. 114/12, abril de 2012.

REPÚBLICA DE COLOMBIA. Corte Constitucional. Sentencia de inconstitucionalidad. C 039 del 2004. M. P.: Rodrigo Escobar Gil. Expediente D-4664.

REPÚBLICA DE COLOMBIA. Corte Constitucional. Sentencia de inconstitucionalidad. C 490 de 2000. M. P.: Alejandro Martínez Caballero. Expediente D-2650.

REPÚBLICA DE ECUADOR. Asamblea Nacional, Proyecto de Código Orgánico General de Procesos, 24 de julio de 2014.

URUGUAY. Senado y la Cámara de Representantes de la República Oriental del Uruguay, Código General del Proceso, 18 de octubre de 1988.

\section{Recursos electrónicos}

LANDONI, Ángel. "El proceso por audiencias en el Código General del Proceso de Uruguay". En: Biblioteca jurídica Virtual del Instituto de Investigaciones Jurídicas de la UNAM, 2013. Disponible en: http://biblio.juridicas.unam.mx/libros/7/3330/26.pdf [consultada el 21 de marzo de 2015].

Portal Administración Justicia, "Guía Práctica del Procedimiento Monitorio". Secretaria General de la Administración de Justicia. Disponible en: https://www. 
El proceso monitorio en Colombia: razones para una objeción

administraciondejusticia.gob.es/paj/PA_WebApp_SGNTJ_NPAJ/descarga/guia\%20 n\%C2\%BA1_monitorio.pdf?idFile=59ce256e-11b1-46d9-b870-3a93d4a65c66 [consultada el 21 de marzo de 2015].

TAPIA, Martha; AGUILAR, Blanca. La violencia nuestra de cada día. 1 Edición. Print E-book. 2014.

\section{Publicaciones científicas}

ARIZA, Libardo. "Malicia indígena: el reconocimiento y la desconfianza en la puesta en marcha del régimen multicultural en Colombia". En: Revista de Derecho Público. No 1. Universidad de los Andes, Facultad de Ciencias Sociales. 1998.

AYMAR, Renato. "A AçãoMonitória Como Instrumento De Recuperação De Crédito Para As Empresas". En: Revista De Direito Privado E Processual Civil Comtemporâneo. No 1. Editora Revista dos Tribunais. 2010.

BALBUENA, Rafael. "Breves comentarios sobre el llamado proceso monitorio". En: Cuadernos de Estudios Empresariales. No 9. Universidad Complutense de Madrid. 1999.

FAIRÉN, Víctor. "Ensayo sobre la evolución del Derecho de Navarra: desde la guerra de sucesión al Código Civil". En: Príncipe de Viana. No 6. Gobierno de Navarra- Institución Príncipe de Viana. 1945.

GOMES, Jose. "A Prova Escrita Na Ação Monitória". En: Revista Jurídica UNIGRAN. No 6. Centro Universitário da Grande Dourados. 2001.

JIMÉNEZ, Marco. "Finding the Good in Holmes's Bad Man". En: Fordham Law Review. V.79. No 5. New York: The Fordham Law Archive of Scholarship and History. 2011.

MARINONI, Luiz, "Reexame Da Prova Diante Dos Recursos Especial E Extraordinário”. En: Revista Genesis de Direito Processual Civil. No 35. 2011. Conselho Federal da Ordem dos Advogados do Brasil.

MARQUÉS, Wilson. "A açãomonitória". En: Revista da EMERJ. No 1. Scola Da Magistratura Do Estado Do Rio De Janeiro. 1998.

MORALES, Jorge. "Mestizaje, malicia indígena y viveza en la construcción del carácter nacional". En: Revista de estudios sociales. No 31. Universidad de los Andes. 2013.

PEREIRA, Santiago. "Los procesos civiles por audiencias en Uruguay. 20 años de aplicación exitosa del Código Procesal Civil modelo para Iberoamérica" En: Revista Internacional de Estudios sobre Derecho Procesal y Arbitraje. No 2. Ministerio de ciencia y Educación - Gobierno de España. 2009.

SÁNCHEZ, Abdón. "Las medidas cautelares en el procedimiento por intimación". En: Anuario de la Facultad de Ciencias Jurídicas y Políticas de la Universidad de Los Andes. No 29. Centro de investigaciones jurídicas - Mérida. 2012. 